\title{
OS TEMPOS DA PALAVRA: O CONCEITO DE RENOVAÇÃO NO CATOLICISMO
}

\author{
Edgar Rodrigues Barbosa Neto \\ Universidade Federal de Pelotas
}

\begin{abstract}
Resumo: Este artigo procura levantar e abordar algumas hipóteses sobre o lugar e o sentido do conceito de renovação no catolicismo, particularmente no que diz respeito ao "regime de historicidade" que ele circunscreve e às formas de experiência religiosa que ele traduz, como suponho seja possível observar a propósito de dois dos "catolicismos renovadores": o da libertação e o carismático.
\end{abstract}

Palavras-chave: catolicismo, Espírito Santo, modernidade, renovação carismática.

Keywords: Catholic Charismatic Renewal, Catholicism, Holy Spirit, modernity.

$$
\begin{array}{r}
\text { Chega mais perto e contempla as palavras. } \\
\text { Cada uma } \\
\text { tem mil faces secretas sob a face neutra } \\
\text { e te pergunta, sem interesse pela resposta, } \\
\text { pobre ou terrivel, que lhe deres: } \\
\text { Trouxeste a chave? } \\
\text { Carlos Drummond de Andrade }
\end{array}
$$

Já é bastante conhecida a presença do conceito de renovação no catolicismo, tornada, aliás, particularmente evidente no período que se segue ao Concílio Vaticano II (1962-1965). Bem menos conhecida, contudo, é a história desse conceito, muito embora já tenhamos à nossa disposição elementos suficientes para levantar, ao menos, a hipótese de sua importância. Acredito que um desses elementos possa ser encontrado naquilo que nos diz Carlo Ginzburg em seu livro Olhos de Madeira (2001). Recordando Amos Funkestein e o seu Theology and Scientific Imagination, Ginzburg 
conta uma história curiosa que teria envolvido, de um lado, o senador romano Volusiano e, de outro, Santo Agostinho. O senador, em certa ocasião, teria, num tom deliberadamente provocativo, perguntado: "como é possível que Deus tenha aceitado de bom grado os novos sacrifícios de cristãos e condenado os sacrifícios antigos, ou seja, as cerimônias judaicas? Teria ele mudad o de opiniāo?" (Ginzburg, 2001, p. 141).

Será possível então que Deus, cuja natureza é ter "dito tudo simultânea e eternamente", tenha mudado de idéia? Agostinho sabe que não e resolverá a aparente contradição recorrendo ao conceito de "adequação" (accommodatio), encontrado por ele no De Oratore, de Cícero. Do mesmo modo que a habilidade retórica de um orador, formado na arte da persuasão, somente pode residir na sua capacidade de expressar-se segundo a orientação de vários estilos, pois os ouvintes que devem ser convencidos de alguma coisa raramente são iguais, também Deus, que é eterno, somente pode dizer a sua própria eternidade fazendo uso daquilo que é, por sua vez, diferente e transitório, já que a lógica do entendimento humano obedece ao princípio mutável que governa a história do mundo. A mudança, portanto, é, na verdade, uma adequação retórica da eternidade, que, para manter-se eterna, deve, necessariamente, ceder às idiossincrasias do tempo.

Os desdobramentos desse conceito podem ser perfeitamente acompanhados reconhecendo-se o duplo aspecto que o tempo assume na obra de Santo Agostinho, particularmente no que se refere à elaboração da sua "teologia histórica", que, como sabemos, é orien tada, ao mesmo tempo, pelo princípio da "estabilidade das formas ou idéias" - as quais ele chama de species - e pelo "fluxo das coisas sensíveis". É Maurice de Gandillac quem nos diz muito claramente isso:

Se tudo foi efetivamente criado de uma só vez, esse ato divino, entretanto, sem o qual tudo retornaria ao nada, nunca cessa. Ainda que "novo", cada dia é, de algum modo, "repetição" do primeiro, pois tudo está presente desde a origem das "razōes seminais" que contêm "causalmente" e "racionalmente" todas as coisas futuras e pelas quais Deus, presente no coração de sua obra, faz nascer e crescer, deixa que definhem e morram essas criaturas que ele pensa, desde sempre, "como nas raízes do tempo". (Gandillac, 1995, p. 17). 
De um modo mais amplo, vale também lembrar aqui que, no hebraico bíblico, como nos diz Walter Rehfeld, o Nome de Deus, o "Tetragrama", deriva do verbo haya, erradamente traduzido apenas por "ser", quando a melhor tradução, de fato, nos permite entendê-lo como designando, ao mesmo tempo, "ser" e "vir a ser". De forma que, no processo denotativo das expressões do tempo na Bíblia Hebraica, não há contradição entre a simultaneidade e a sucessão (Rehfeld, 1988). Frente a isso, é possível, neste momento, adiantar uma questão que, como se verá, é de enorme importância para o argumento a ser desenvolvido neste artigo: tanto o conceito de adequação quanto o conceito de renovação representam, analogamente, formas de lidar com o problema da mediação entre aquilo que é, como foi dito acima, simultâneo, sempre parecido consigo mesmo, e aquilo que é, de outro modo, sucessivo, sempre diferente de si mesmo. O universo de problemas que ambos os conceitos parecem recobrir é, portanto, aquele da "semelhança" (Velho, 1997), ou seja, daquilo que, pressupondo a descontinuidade entre o tempo do mundo e o tempo de Deus (ou mesmo entre o tempo da sociedade e o tempo da religião), vê-se obrigado a jogar com a dificuldade de, não os tendo como iguais, não poder, da mesma forma, tomá-los como completamente diferentes, estranhos um ao outro.

Sendo assim, as questôes que o conceito de adequação suscita são, como tentarei demonstrar no decorrer deste texto, estruturalmente homólogas àquelas suscitadas pelo conceito de renovação, em particular o fato de ambas parecerem colocar, lado a lado, uma experiência do tempo e uma experiência da linguagem, essa última, por sua vez, claramente atravessada por uma dimensão "política", tal como se pode depreender daquela significação retórica - ali referida como persuasão e convencimen to - que o conceito de adequação parece poder assumir. Gostaria, no entanto, de esclarecer que não é a minha intenção escrever aqui a história do conceito de renovação. Trata-se apenas de levantar e discutir algumas hipóteses muito gerais que talvez possam, de outro modo, estimular a sua possibilidade. Tentarei agora sintetizá-las em duas, para depois demonstrar a maneira por meio da qual elas puderam ser aplicadas. 
A primeira delas pode ser formulada do seguinte modo: o acontecimento da volta, presente em quase todos os catolicismos ${ }^{1}$ que assumem como horizonte a tarefa de renovar a religião católica e/ou cristã, só é possível porque aquilo que é encontrado antes, por exemplo na origem do cristianismo, é parte simultânea do que está depois, seja ele o presente do qual se parte ou mesmo o futuro que se espera. De tal forma que a origem, um dos referentes da volta, apenas pode ser acessada no permanente deslocamento que a faz, para além da sua estabilidade, circular no tempo. ${ }^{2}$ Logo, como se poderá perceber, a repetição não instaura, relativamente àquilo que ela repete, uma relação de identidade, mas sim uma relação de duplicação.

Dito de outra maneira, isso significa que o conceito de renovação descreve uma "experiência analógica" do tempo, que, a partir de uma relação em espiral, articula o passado, o presente e o futuro, estabelecendo entre eles um jogo especular, no interior do qual a identidade de cada um apenas

1 Todas as vezes em que for u tilizada a expressão "catolicismos ren ovadores", estarei pensando, particularmente, no catolicismo carismático e no catolicismo da libertação. A minha hipótese é que ambos autorizam uma leitura similar do conceito de renovação que, sem desconhecer as suas distinçōes, permite, no entanto, pensá-las como situadas em relaçóes de contigüidade. Assim, o conceito de renovação, no modo como procuro descrevê-lo aqui, atravessa as formas de sua utilização naqueles dois catolicismos. Daí a necessidade de pensá-lo como algo que é compartilhado não a despeito dos usos diferenciados que comporta, mas sim através das diferenças que podem ser observadas nos modos de utilizá-lo. Por isso, a renovação é sempre renovaçôes. Tratarei, sinteticamente, do catolicismo da libertação no final deste artigo. Quanto ao catolicismo carismático, remeto o leitor à minha dissertação de mestrado (Barbosa Neto, 2000). Também seria possível in cluir aqui as discussões a respeito da chamada "in cultura ção", questão fun damental, conforme tem demonstrado Paula Montero (1996), para entender a atuação da Igreja no período pós-conciliar.

2 Paul Ricoeur nos fala do paradoxo de um Deus criando imutavelmente coisas mutáveis, diante do qual, para os homens, o "início não é um passado que passou, mas um início incessantemente con tinuado” (Ricoeur, Lacocque, 2001, p. 86). Em face disso, é provável que o problema da origem também possa ganhar sentido na temporalidade potencialmente reversível que articula as três figuras da Criação, da Revelação e da Redenção. Ainda é Paul Ricoeur quem nos diz: "O sempre-já-ali da Criação não faz sentido independentemente da futuridade perpétua da Redenção. Entre estes dois está intercalado o eterno agora do vocês, amem-me. Talvez seja nesse eterno agora que nasça a proclamação: Eu sou aquele que é..." (Ricour; Lacocque, 2001, p. 87, grifo dos a utores). 
pode ser estabelecida pela semelhança com um outro que não é ele. De modo que, por exemplo, o passado é parecido com ele mesmo pela sua semelhança, digamos, com o presente, fazendo assim com que ambos possam diferir de si mesmos, parecendo-se, no entanto, entre si, e de si para consigo, como se cada um estivesse duplicado num outro que é e não é ele. Em outras palavras, uma experiência do tempo que não parece corresponder nem à circularidade do mito, embora conserve o seu apelo à identidade, nem à irreversibilidade da história, embora também aqui mantenha a sua abertura à diferença.

A segunda hipótese, por sua vez, assume aqui o seguinte formato: à medida que o catolicismo realiza-se como religião, entre outras coisas, também por meio de uma ética do dizer, isto é, por meio do dever de sempre ter algo a comunicar para alguém, o conceito permite pensar o "regime de

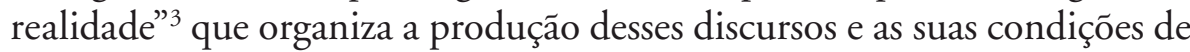
existência. Nesse caso, acredito que o problema seja este: supondo que, sobretudo do ponto de vista da religião institucional, dizer é parte integrante do crer, como então organizá-lo de modo que ele seja a tradução da crença? Por outro lado, e intimamente vinculado a essa primeira pergunta, tem-se também o seguinte: se não basta acreditar para que se tenha conhecimento daquilo que deve ser dito, como então é possível, ao dizer, permanecer idêntico àquilo em que se acredita? De outro modo, como é possível dizer aquilo mesmo em que se crê? Como sabemos, essas são questões que têm aberto um amplo espectro de discussões a respeito dos modos de produção da crença religiosa na sociedade moderna, envolvendo questóes relativas à linguagem e à política, as quais têm marcado, inclusive, importantes

${ }^{3}$ Por "regime de realidade", enten do aqui, gen ericamente, o seguin te: as con dições que devem ser preenchidas para que uma determinada experiência, seja qual for a sua natureza, possa ser reconhecida como fazendo parte de algo que é identificado como real. Uma tal definição está, evidentemente, muito próxima do modo como Michel de Certeau conceituava a "crença”. Dizia ele: aquilo que a define não é o seu objeto, "mas o investimento das pess oas em uma prop os ição, o ato de enu nciá-la considerando-a verd ad eira nou tros termos, uma modalida de da afirmação e não o seu conteúdo" (Certeau, 1994, p. 278). Um "regime de realidade" pressupôe, de algum modo, um investimento de credibilidade. 
reflexões no campo da teologia, como, por exemplo, aquelas que Henrique de Lima Vaz (1986) agrupou sob a rubrica, aliás bastante sugestiva, de "linguagens de emprésti mo". Voltarei a esse ponto mais adiante.

Convém agora partir de uma observação: desde o Concílio Vaticano II assiste-se a um enorme investimento católico de sentido no conceito de renovação. O teólogo e historiador José Oscar Beozzo recorda que, ao pedir a seus alunos que traçassem aquelas que lhes pareciam ser as grandes etapas da história da Igreja no Brasil, obteve como resposta quase unânime a seguinte definição: "Antes e depois do Concílio" (Beozzo, 1994, p. 14). "Antes" e "depois" lembra muito, e não é casual que assim o faça, a si mbologia daqueles nascimentos místicos que estruturam os ritos iniciáticos como "mutações on tológicas do regime existen cial" (Eliade,1959, p. 12, tradução minha). "Antes" e "depois": crivo mítico na temporalidade, marco zero de um novo começo. ${ }^{4}$ Uma primeira aproximação pode ser feita: o conceito de renovação tem, na idéia de renascimento, um correspondente próximo.

Contudo, ao mesmo tempo em que há um significativo investimento de crença nesse conceito, insinua-se sobre ele um relativo silêncio. Nos dicionários bíblicos e teológicos organizados por Albert Vincent (1969), John Mackenzie (1983) e A. Van den Born et al. (1985), em que pude pesquisar, apenas nesse último é possível encontrar um verbete que trata especificamente do conceito de renovação, e mesmo assim de um modo sucinto se comparado aos demais. Já no Vocabulário de Teologia Bíblica, organizado por Xavier León-Dufour et al. (1984), pude observar o estabelecimento curioso, e sob certo aspecto revelador daquela primeira aproximação, de uma equivalência entre renascer e renovar, num verbete referente ao primeiro conceito. Ambos são, a seu modo, indícios importantes do sentido de renovação, e voltarei a falar deles mais tarde. Por outro lado, no que se refere a trabalhos propriamente teológicos, o único que encontrei e que discute este conceito é o livro do teólogo brasileiro Francisco Catão, que

\footnotetext{
${ }^{4}$ Nada menos do que a entrada para uma nova era da história da Igreja é o que o Concilio Vaticano II significa para Karl Rahner. Para ele, "era" quer dizer um ponto de parada na contagem do tempo, isto é, onde pára tudo quanto marcou o tempo anterior, e onde começa uma coisa inteiramente nova, que nunca havia existido antes (Greinacher, 1994, p. 8, 10).
} 
trata especialmente da Renovação Carismática Católica, muito embora faça referências importantíssimas às questôes que me interessam abordar neste artigo, como terei oportunidade de demonstrar um pouco mais adiante (Catão, 1995). Por enquanto, quero somente chamar a atenção para a economia das análises feitas sobre o conceito de renovação, que possui, em contrapartida, um uso destacadamente disseminado.

Suponho que a presença generalizada desse conceito, acrescida de sua pouca tematização, façam dele um conceito não-objetivado, cujo sentido atua como pressuposto tácito de sua utilização. De outro modo, torna-se desnecessário esclarecê-lo, pois é como se todos soubessem de antemão do que se trata. Mesmo algumas pesquisas importantes no campo das ciências sociais deixaram de considerar esse problema. Em alguns casos, ao contrário, o que se vê é a contribuição, certamente não-intencional, para que se reproduza o sentido como aquilo que é dado. Um bom exemplo são os trabalhos que procuram classificar a renovação em conservadora ou progressista, esquecendo-se que as classificações são, na maior parte das vezes, atribuições e auto-atribuições dos próprios grupos que se intitulam legítimos renovadores na disputa com outros grupos que reivindicam o mesmo para si. ${ }^{5}$ Desse modo, o exercício classificatório parte do conceito como se

\footnotetext{
5 As obras mais importantes desse modo de análise, pela riqueza das informaçôes que trazem, são as de Oliveira (1978) e Prandi (1997). Ambas abordam o catolicismo carismático comparando-o, de forma mais ou menos explícita, com o catolicismo da libertação. A conclusão a que chegam é praticamente a mesma: de um lado, a experiência dos carismas é uma experiência institucionalizada que não chega a acrescentar nada de substancialmente novo à vida da Igreja, de outro, a mesma experiência faz a libertação refluir para o interior do indivíduo, esquecendo-se do vínculo social e coletivo que a caracterizava no catolicismo da libertação. De modo que, por caminhos diversos, o resultado, contudo, coincide: a renovação carismática é uma renovação conservadora. Em minha dissertação de mestrado, já citada anteriormente, tentei trilhar um caminho alternativo de análise, desenvolvendo a hipótese segundo a qual o conceito de renovação parece melhor designar uma reprodução das formas institucionais, o sacramento do batismo é um bom exemplo disso, mediante a recriação carismática do sentido referente àquilo que é ser uma instituição. Como, no entanto, não há espaço aqui para reproduzir os argumentos que desenvolvo naquele trabalho, e que me permitiram chegar àquela conclusão, devo, novamente, remeter, a ele, o leitor (Barbosa Neto, 2000).
} 
ele fosse um dado ao qual deve ser agregada uma adjetivação política, que cumpre a única função de hierarquizar o sentido do que é renovar, deixando no impensável justamente a lógica que preside o processo de fabricação desse sentido.

Ao contrário, portanto, de substantivar o conceito, acrescentando-lhe predicados, é necessário interpretá-lo de modo a torná-lo capaz de funcionar como um espaço que permite descrever não apenas relações de antagonismo (progressistas $\mathrm{x}$ conservadores), as mais comumente observadas, mas também relações de coexistência. Com isso, é claro, não se trata de introduzir uma identidade onde, de fato, ela não existe, mas sim de compreender o "regime de reali dad e" por meio do qual o con ceito, definidas as suas condiçôes de emergência, permite reconhecer, no jogo político e institucional das proximidades e das distâncias, algumas coisas como sendo parecidas e outras como sendo dessemelhantes.

Acredito que uma modificação metodológica desse tipo possa definir outros problemas de investigação. Aqui, procurarei abordá-los situando-os no espaço de duas perguntas, de algum modo já sugeridas no início deste texto, e que vejo como sendo amplas o suficiente para que possam, ao mesmo tempo, circunscrever um universo de questões, permitindo vislumbrar novos domínios de pesquisa: qual o sentido mais geral do conceito de renovação e que condições o tornam possível? Para tal, proponho agora retomar o primeiro verbete a que me referi anteriormente, pois ele fornece algumas pistas importantes para que se possa encaminhar algum tipo de resposta a essas duas questôes. O autor, A. Van Shaik (1985), realiza uma exegese bíblica desse conceito que vale a pena ser seguida, mesmo que a minha intenção não seja, a princípio, exegética.

Digo a princípio, porque gostaria de esclarecer, neste momento, o que será entendido aqui por exegese, já que, de algum modo, esse entendimento permanecerá, no restante do texto, como uma espécie de linha subjacente àquilo que será dito. Um trecho do discurso do papa João XXIII, pronunciado na primeira sessão do Concílio, facilitará este esclarecimento:

As circunstâncias hodiernas, as exigências dos últimos cinqüenta anos, o aprofundamento doutrinário nos colocaramde frente a realidades novas, como 
disse no discurso de abertura do Concílio. Não é o evangelho que muda: somos nós que começamos a compreendê-lo melhor. (Beozzo, 1994, p. 21, grifo meu).

A Escritura, portanto, não se modifica, mas a sua compreensão muda, e muda para melhor. As "realidades novas" abrem a probabilidade de uma melhoria na compreensão do texto, que é, supostamente, a tradição que se mantém igual a si mesma. Ao acatar o novo como a possibilidade de melhor compreender o seu sentido, como se ele estivesse fixado na condição de uma leitura possível, a hermenêutica bíblica acaba por levar adiante esse sentido, e, dessa forma, faz do texto outra coisa, enquanto ele continua, no próprio movimento que instaura a diferença, a parecer o mesmo. É dessa forma que a exegese aparece, ao mesmo tempo, como uma eisegese, onde a extração de um sentido fixo do texto é parte inseparável da produção desse mesmo sentido, ${ }^{6}$ onde a interpretação aparece como um jogo ambivalente entre a estabilidade e a flexibilidade, entre o desde sempre presente e o inteiramente novo; onde, portanto, a busca pelo sentido e a invenção do sentido são partes consubstanciais de um único movimento, do qual o conceito de renovação se mostra como condição e efeito. ${ }^{7}$ De fato, como sugeri logo acima, ao dizer isso já estou, de alguma maneira, antecipando a linha principal que o meu argumento deverá seguir. Desejaria, no entanto, desenvolvê-lo mais vagarosamente. Por esse motivo, sugiro então retornar àquele verbete.

Van Schaik (1985) demonstra que o substantivo renovação não se encontra no hebraico nem no grego do Antigo Testamento (AT). Por sua vez, ele aparece no Novo Testamento (NT) com dois sentidos muito diferenciados, ainda que ambos designem a palavra novo. A diferenciação é, portanto, basicamente semântica. De um lado, novo representa tudo que é

${ }^{6}$ Sobre a exegese bíblica como um procedimento hermenêutico que combina uma relação de duplo sentido com o texto, ver Croatt (1987).

7 A distinção de Congar entre Tradição e tradições, como uma tentativa de clarificar o que é substancial e o que é acidental na Tradição, parece estar inserida neste processo (Congar, 1960; Kerkhofs, 1999). 
qualitativamente diferente e melhor, de outro, funciona como um indicador do que é recente. No primeiro caso, novo é utilizado como um adjetivo, enquanto que, no segundo, aparece como substantivo. Segundo o autor, a primeira atribuição é a predominante, sendo a segunda, por seu turno, bastante rara.

No entanto, ainda que a palavra não se ache presente no AT, o autor julga poder discernir as coisas que ela designa, como se fossem, na realidade, anteriores à própria palavra. Na sua opinião, o tema da renovação aparece sobretudo no contexto das esperanças do futuro e da salvação, principalmente no discurso dos profetas. Isaías, Jeremias e Ezequiel, ao descreverem a salvação vindoura, o fazem, freqüentemente, em termos de renovação. Israel não deve mais se lembrar do passado, Javé agora vai fazer coisas novas (Is 43,18), revelar coisas novas $(48,6)$. A futura obra salvífica de Deus, além de ser um novo êxodo, será mesmo uma nova criação (Is $41,20 ; 45,8 ; 48,6 s s)$. Javé criará um novo céu e uma nova terra $(65,17$; $66,22)$, tudo será novamente como no paraíso (51,3; 36,25, grifo meu). Os diversos aspectos soteriológicos da aliança passarão por uma renovação: haverá um novo Davi (Ez 34,23ss), um novo templo (40-43), uma nova Jerusalém (Is 54,11-17).

Após ter examinado a recorrência da palavra renovação nas coisas enunciadas profeticamente como novas, o autor curiosamente conclui dizendo que a observação pessimista - é assim que ele a qualifica - presente em Eclesiastes (cap. 1, versículo 9) não se enquadra muito bem com as esperanças proféticas de um futuro inteiramente novo: "o que foi será; não há nada de novo debaixo do céu". ${ }^{8}$

Van Schaik (1985) vê, no NT, o começo da presentificação da profecia do novo. A nova criação anunciada no AT tem início em Cristo, o novo Adão. Também a Igreja pode ser chamada de "o novo homem". Mesmo

\footnotetext{
8 Segundo a Bíblia de Jerusalém, a tradução é a seguinte: "o que foi, será, / o que se fez, se tornará a fazer: / nada há de novo debaixo do sol”. O versículo 10 dá con tin uidade a essa mesma idéia: "mesmo que alguém afirmasse de algo - Olha, isto é novo! - eis que já sucedeu em outros tempos antes de nós".
} 
todo cristão já é, em princípio, uma nova criatura (2Cor 5,17; Ef 2,10). João fala de um novo nascimento $(3,15)$. Renascimento. O mais importante de tudo isso é, a saber, o uso que o autor faz do conceito de renovação, tornando-o equivalente à emergência radical do novo, sempre entendido como aquilo que é melhor. Todo o verbete, por assim dizer, é escrito sob o signo do novo.

No Vocabulário de Teologia Bíblica (León-Dufour et al., 1984), no verbete referente ao conceito de tempo, há uma alusão a essa associação, inclusive citando a mesma passagem do Eclesiastes como uma exceção - aqui também a chamam de pessimista - à concepção de tem poralid ade que seria a predominante no texto bíblico. Vejamos o que diz o texto. A Bíblia representaria uma ruptura na percepção mítica que até então havia predominado sobre o tempo. Ultrapassando a idéia do eterno retorno - referida à reiteração permanente do que se encontra na origem - o tempo cristão seria orientadopela sua representação sacralizadada história,entendida como um fluxo irreversível de acontecimentos únicos. É nela, afinal, que tem lugar a revelação.

O argumento é o seguinte: nas religiões precedentes o tempo histórico possuiria uma natureza profana, pois o acontecimento particular apenas teria importância na medida em que estivesse reproduzindo a história primordial dos deuses, numa lógica muito próxima à dos ciclos naturais. Tratava-se aí de uma sacralidade mítica. Nesse ponto, afirma o verbete, a revelação bíblica inova de forma radical. Nela, Deus se manifesta através da história, tornando-a sagrada. E os acontecimentos de que ela é tecida aparecem como sendo os seus atos aqui na terra. Por isso é que o tempo, em que esses acontecimentos se inscrevem, tem por si mesmo um valor sagrado: não pelo fato de repetir o tempo primordial em que Deus criou o mundo, mas pelo fato de trazer coisa nova, à medida que as etapas do desígnio divino se sucedem, tendo cada uma sua significação particular. A história torna-se, ela própria, uma teofania.

De acordo com esses dois verbetes, o conceito de renovação é um equivalente semântico do conceito de inovação. $O$ que nos leva a concluir que ele tem uma relação muito especial e estreita com o tempo e, em particular, 
pelo que foi visto até então, com o futuro. No entanto, há que se prestar atenção, através daquilo que dizem os próprios autores, a uma certa referência ao passado que também parece acompanhá-lo. Veja-se a seguinte afirmação: "tudo será novamente como no paraíso", ou "será mesmo u ma nova criação". Aqui a renovação passa a designar o reencontro do que se perdeu no passado, portanto não mais o absolutamente inédito, mas o renascimento, o nascer de novo. O passado aparece como o referente do novo. Desse modo, não é totalmen te exato chamar a passagem do Eclesiastes - "o que foi será; não há nada de novo debaixo do céu" - de pessimista, pois, ao que parece, toda esperança profética de futuro é lembrança do passado original que começa a atualizar-se no tempo histórico onde tem lugar a revelação. O tempo soteriológico, linear e histórico, e o tempo mítico do eterno retorno não se anulam. ${ }^{9}$ No que se refere ao conceito de renovação, e aqui se tem já uma segunda aproximação, a profecia é memória do futuro.

Não obstante isso, aquela associação entre renovação e inovação é bastante comum de ser encontrada. Inovar é o sentido implícito que está presente no uso mais corriqueiro dessa palavra. Um texto relativamente recente de Alberto Antoniazzi (1993) é um ótimo exemplo dessa utilização. Nele o autor procura construir uma análise geral do catolicismo no Brasil, englobando os vários tipos sociais que ele assumiu e assume em nossa história, desde o catolicismo popular tradicional, passando pelo catolicismo romanizado, até o catolicismo atual, principalmente o do contexto PósVaticano II. Pois bem, no caso deste último, Antoniazzi argumenta que a conjuntura do catolicismo, isso vale para o momento que corre, está marcada por um forte embate entre renovação e conservação, cujo resultado pode nos conduzir a pensar, por um lado, em ruptura e, por outro, pode nos

9 Jorge Luis Borges, em sua famosa conferência sobre o tempo, fez uma observação bastante curiosa a esse respeito: "El tiempo es sucesivo porque habiendo salido de lo eterno quiere volver a lo eterno. Es decir, la idea de futuro corresponde a nuestro anhelo de volver al principio. Dios ha creado el mundo; todo el mundo, todo el universo de las criaturas, quiere volver a ese manantial eterno que es intemporal, no anterior al tiempo ni posterior; que está fuera del tiempo.” (Borges, 1989, p. 126). 
levar a indagar sobre a permanência do passado no presente. Opondo-se à idéia da continuidade, o conceito de renovação encontra, no princípio do novo, o referente de sua aplicação.

A minha hipótese é de que esta leitura do conceito disseminou-se no contexto Pós-Concílio Vaticano II. ${ }^{10}$ E, nesse sentido, o verbete visto anteriormente parece esclarecer não apenas a origem do conceito, como também, e talvez principalmente, o lugar de onde o autor fala (aliás, como sugeri antes, na operação exegética essas duas coisas se confundem). Pois não se pode esquecer que a palavra renovação, segundo o próprio autor, pouco aparece no texto bíblico e que, no entanto, ele a localiza justamente naquelas passagens em que o termo novo (adjetivo) é utilizado. Essa equivalência não será, antes, fruto do uso que ele faz do conceito de renovação? A passagem do Eclesiastes, ele a chama de pessimista. Ora, toda adjetivação é, antes de qualquer coisa, circunscrição de um espaço sobre um lugar substantivo: "antes" e "depois". O Concílio é, ele próprio, símbolo do que é novo. Aparece inscrito, na história recente do catolicismo, sob a égide da ruptura. E assim o é, porque pela primeira vez a Igreja aceitou a sociedade moderna naquilo que ela tem de novo, "naquilo que ela tem de melhor". Renovação torna-se sinônimo do que é novo através da positivação da "novidade moderna", leia-se aqui, em particular, a au tonomia da sociedade em relação à religião católica cristã.

Porém, a "novidade moderna" nem sempre foi percebida dessa forma. E mesmo então, o conceito de renovação já era utilizado, de um modo, contudo, bem distinto dessa equivalência com a palavra novo, ou melhor, diferente desse modo de empregá-la que se tornou comum para nós. É o que procurarei demonstrar em seguida. Antes, no entanto, é preciso abrir um pequeno parêntese para voltar, de maneira um pouco modificada, àquilo mesmo que era dito no início deste artigo.

\footnotetext{
${ }^{10}$ Sobre a recepção do Concilio Vaticano II no Brasil, ver Beozzo (1994); para uma compreensão mais geral, consultar Aubert e Hajjar (1976) e também o artigo de Ladrière (1986).
} 
Do muito que se pode dizer a propósito da ruptura mencionada anteriormente, cujo sentido, em parte, vincula-se àquilo que o conceito de secularização ${ }^{11}$ parece muitas vezes significar, importa, neste momento, reter apenas um ponto. De algum modo, o conceito de adequação mencionado antes parece trazer em si mesmo o pressuposto dessa ruptura, já que, como se pôde ver, o problema que ele traduz não apenas estabelece uma disjunção entre o tempo do mundo, marcado pelo imperativo da mudança, e o tempo da eternidade, que define aquilo que é como sendo desde sempre - fato que indica ou pelo menos prenuncia uma separação entre sociedade e religião - como também impõe a necessária tarefa de relacioná-los entre si, reconhecendo na mudança, tanto aquela que já foi quanto aquela que virá, algo previamente definido na forma de uma presença virtual na história. Para fazer uso de uma terminologia já antiga, pode-se dizer que, à luz desse conceito, o conteúdo histórico da mudança existe como um possível nas formas da eternidade.

Logo, podemos concluir, de outra maneira, que o eterno não é eterno porque faz tabula rasa do tempo, mas sim porque faz do tempo, isto é,

\footnotetext{
${ }^{11}$ Não é o meu objetivo entrar no mérito dessa discussão. Aqui apenas menciono um texto, de orientação geral, que consegue, de maneira satisfatória, captar os vários sentidos do conceito de secularização, e, em particular, aquele ao qual estou me referindo: secularização como um processo que coloca o princípio da alteridade no campo das relações entre a sociedade e a religião; ver Guizzardi e Stella (1990). Nessa mesma linha, seguindo agora Peter Beyer (1994), secularização é definida como dissociação entre a função religiosa, entendida como aquilo que seria específico à religião, e o desempenho religioso, isto é, a presença desse específico para além do campo da própria religião. Os problemas relativos à passagem do crer ao dizer, aos quais fiz referência anteriormente, e também os problemas a respeito dos limites do campo religioso, onde começam e onde terminam, ganham uma significação importante no quadro mais amplo descrito pelo fenômeno da secularização. Logo, é preciso afirmar que ela não significa, ou pelo menos não automaticamente como às vezes se supõe, privatização, mas sim um redimensionamento da presença pública da religião, como sugere, aliás, o próprio Peter Beyer. É ele também quem chamou a nossa atenção para o fato de que, nos movimentos ascéticos e místicos do Ocidente, a função e o desempenho religioso já estavam se tornando, pela primeira vez, nitidamente diferenciados, prenunciando o problema da religião na sociedade moderna: a identidade do religioso na autonomia da sociedade e de suas esferas sociais. (Beyer, 1994, p. 405).
} 
daquilo que não cessa de instaurar a diferença, a expressão contínua de sua manifestação. O sempre que ele é, é o sempre do sempre igual apenas por ser o sempre do sempre outro.

Assim, aquilo que, a princípio, parece ser um congelamento da mudança na eternidade, acaba por fazer com que a própria eternidade pareça, a todo momento, diferente dela mesma, já que a definição a respeito do que virá pertence àquele que somente pode revelá-la, de forma simultânea, no plano da sucessão. Por isso, e este me parece ser o ponto chave, o retorno ao passado pode ser, como de fato parece sempre ser, um retorno ao presente ou mesmo ao futuro, já que o passado, não sendo somente um tempo que passou, pode estar agora, ainda aqui, e mesmo depois, quando esse aqui já for, para nós, um outro aqui. De tal modo que aquilo que não muda somente pode ser mostrado através daquilo que não cessa de mudar.

Suponho que seja possível encontrar aqui um ponto de apoio que confirma o que Alphonse Dupront (1995) dizia ser o específico do catolicismo e mesmo da Igreja Católica, marcados que estão, esses dois, por uma "ascese da ambivalência”, ${ }^{12}$ cuja definição nos permite discernir, no exercício dessa

\footnotetext{
${ }^{12}$ Um ótimo exemplo dessa ambivalência pode ser perfeitamente encontrado nas palavras de Pierre Sanchis: "[...] existe inegavelmente, nos documentos emanados da primeira geração cristã, a consciência de uma libertação relativamente aos laços que, tradicionalmente...constituíam o universo religioso institucional...Segundo esta leitura, com o advento do Logos feito Carne, sua Ressurreição, o Sacrifício perfeito estava definitivamente consumado. Doravante, em substituição a todos os ritos e toda mediação 'religiosa' institucional, os camin hos estavam abertos para a 'realidade' (a 'res') que o regime religioso havia anunciado simbolicamente: um encontro direto (a 'fé') entre a Humanidade, através da opção decisiva de cada um dos seus membros individuais, e Deus. Esta profun da intu ição constitui, sem dúvida, parte substancial da 'novidade' cristã. Enquanto tal, o catolicismo não poderia eliminá-la ou desconhecê-la. Ao contrário, o que caracteriza desde o in ício o 'filão católico' como um sincretis mo é precisamente a convivência e a tensão ativamente mantida, nele, entre, por um lado, esta dimensão do cristianismo, que tende para a ruptura com a religião e a conseqüente supressão de todo o aparato simbólico e coletivo tido tradicionalmente por 'religioso', e, por outro lado, a sua modalidade 'católica', que tende, ela, e ao contrário, a valorizar a mediação, o instrumental coletivo de religião, a delegação institucional, o Sacramento no seu aspecto mais visível." (Sanchis, 1993, p. 10). Ver também Sanchis (1986).
} 
forma de religião, uma disciplina que delimita uma duplicidade existencial, impondo, a esse mesmo exercício, a necessidade de, simultaneamente, definir um pertencimento ao mundo e um "regime de estrangeiridade" em relação a ele. ${ }^{13}$ De forma que a ambivalência que regula as relações entre o visível e o invisível no catolicismo também combina um sentido de presença e um sentido de ausência a partir dos quais o mundo pode ser experimentado, simultaneamente, como autônomo relativamente à religião, as histórias internas da secularização, ${ }^{14}$ como sabemos, têm lugar nesse ponto, e como a única maneira pela qual se pode vivê-la. A presença de Deus é aquilo que, ao mesmo tempo em que deve exceder ao mundo, delimitando o lugar necessário de uma falta, apenas pode ser uma presença manifestada no mundo, transformando-o, esse último, numa espécie de duplo de Deus,

13 "Ha de considerarse al mundo como manifestación y negación de Dios, al mismo tiempo. La vida en esta contradicción constituye, por decirlo así, la sustancia de la fe cristiana." (Kolakowski, 1971, p. 73).

${ }^{14}$ Alguns historiadores sugerem que se deve recuar, pelo menos, até às reformas dos séculos XII e XIII, período que foi inclusive denominado de Reforma da Idade Média, para que se possa compreender a secularização como um processo de longuíssima duração. Isso seria particularmente evidente pela observação, que vale para esse período, da emergência de movimentos laicos no seio da própria instituição, mas também às suas bordas, que estariam colocando em questão, ainda que de um modo incipiente, o monopólio da gestão dos bens de salvação. No interior dos embates que opuseram dois modelos soteriológicos, o da vita angelica e o da vita apostolica, o primeiro mais relacionado com a renúncia ao mundo pela reclusão monástica e contemplativa e o segundo com a idéia da comunicação da palavra de Deus por meio de uma ação no mundo, pôde emergir não apenas a crença na necessária universalidade daquela palavra, tanto do ponto de vista de quem a recebe quanto de quem deve portá-la, como também o princípio segundo o qual a salvação pode ser obtida através de uma vida ativa, capaz de apropriar-se do mundo no próprio ato de aproximar-se de Deus. Antes mesmo desse período, ainda no século XI, as polêmicas a respeito da formação e do desenvolvimento de grupos de cônegos regulares, que deveriam, ao mesmo tempo, viver no mundo sem confundirem-se com o mundo, serem, num único movimento, padres e monges, confirmam, por um lado, aquilo que Alphonse Dupront (1995) diz ser a especificidade da religião cristã, e, por outro, dão início a um conjunto de modificações cuja importância os séculos vindouros viriam a atestar. Ver Bolton (1983). 
princípio simultâneo de sua afirmação e negação, o mesmo e o outro de sua existência. ${ }^{15}$

Pois bem, e para dizer da forma mais direta possível, é na confluência dessa dupla alteridade, que distende o tempo (também o espaço) entre um visível sempre outro (história) e um invisível sempre igual (mito), impondo, ao mesmo tempo, a complicada tarefa de fazê-los, de algum modo, coincidir, é justamente aí, enfim, que se pode ler ou encontrar o sentido mais geral do conceito de renovação: realizar o eterno no histórico, colhendo, na própria história, os indícios daquilo que é, por definição, sem história, ${ }^{16}$ definindo,

${ }^{15}$ Dois textos, um relativamente antigo, de Gerd Borheim, e o outro, mais recente, de Gianni Vattimo, ilustram, por meio das posiçóes contraditórias que assumem a respeito de Santo Agostinho, a ambivalência que, segundo Alphonse Dupront (1995), talvez seja constitutiva do próprio catolicismo. Segundo Gerd Borheim, a doutrina agostiniana das duas cidades leva a um excesso de inimizade pelo mundo, pelo corpo e pelo sensível, resultando numa platonizaçáo do cristianismo diante da qual emerge uma recusa a pensar o móvel, o mutável e o contingente. "Recusando-se a pensar o outro que não o ser no movimento, fazendo do permanente e do imutável a medida da verdade, Santo Agostinho impede o acesso ao pensamento da História [...] E enquanto dura a Metafisica - compreendida como esquecimento do ser - a História não poderá ser pensada sem atender às imposições da tradiçáo platônicoagostiniana." (Bornheim, 1972, p. 23). A posição de Vattimo, embora formada no mesmo campo de leitura aberto por Heidegger, é o exato oposto da de Borheim: "A partir de Santo Agostinho e de sua reflexão sobre a Trindade, a teologia cristã é, desde as suas bases mais profundas, uma teologia hermenêutica: a estrutura interpretativa, a transmissão, a mediação e, talvez, a deiettività não concernem somente ao anúncio, à comunicação de Deus com o homem; caracterizam a própria vida íntima de Deus, que exatamente por isso não pode ser pensada nos termos da plenitude metafisica imutável [...]" (Vatimo; Der rida, 2000, p. 102).

${ }^{16}$ A esse propósito, vale registrar aqui o que dizia, há alguns anos, Clodovis Boff (1982, p. 6), ecoando a resposta de Santo Agostinho ao senador romano Volusiano: "[...] a descontinuidade na teoria da fé é também radical. É radical porque se enraíza nas raízes mais profundas da própria fé (e não porque deitaria novas raízes). Mas em que mudaria a fé? A fé muda em sua manifestação histórica, em sua forma de expressão, em suas mediaçóes culturais concretas [...]" Poderíamos perfeitamente dizer que a mudança é radical porque faz parte do que há de mais permanente na permanência da fé: a mudança, portanto, não apenas é a permanência como também, e mais ainda, é a radicalidade dessa permanência. "[A igreja] muda para ser fiel. Se a Igreja permanecesse sempre igual ao longo da história, ela trairia sua missão. Ela muda de forma para ser fiel ao conteúdo: o Evangelho de Jesus Cristo. Assim também em teologia: a simples repetição de um dogma dentro de um contex to histórico mudado, longe de representar ortodoxia, significa antes traição desse dogma. Por isso, só uma teologia moderna é uma teologia ortodoxa [...]" (Boff, 1982, p. 6). 
enfim, os meios através dos quais ambos possam comunicar-se, de modo a continuar distintos, sem serem completamente estranhos um ao outro. Trata-se, portanto, de eliminar, para lembrar aqui da expressão de Otávio Velho, a exótica da diferença, e não a diferença em si mesma (Velho, 1997 , p. 48). Trata-se igualmente daquilo que dizia o cardeal Suhard: "a cada instante, a Igreja deve ao mesmo tempo ser e vir a ser. Ser sem alterações na sua realidade invisível e vir a ser século após século em sua realidade visível” (Vincent, G., 1992, p. 410). De outra maneira, um trabalho na ruptura, contra a ruptura e incapaz de suprimir a própria ruptura contra a qual trabalha. Fecha-se aqui o parêntese.

No entanto, como é bem conhecido, essa ruptura foi por longo tempo negada enquanto tal, e isso sobretudo nos movimentos que tinham por base o projeto de reconstrução de uma sociedade cristá. Toda restauração, que daí resulta, traz consigo a sombra não reconhecida dessa separação, imagem que tenta ocultar de si própria a perda que a constitui: negação da alteridade que instaura a sociedade como esfera separada da religião. Sob certo aspecto, o prefixo re é bem a tradução deste "autoengano": recristianização é uma forma arrevesada de dizer descristianização.

O próprio catolicismo social, considerado um marco importante na virada das relaçóes entre a Igreja Católica e a modernidade, encontra-se situado nesse processo. Desenvolvido principalmen te a partir da segunda metade do século XIX, obtém o seu "reconhecimento eclesiástico" em 1891, por ocasião do aparecimento da Rerum Novarum, primeira encíclica social da Igreja (Leão XIII, 1891). Trata-se, essa encíclica, do modo católico de apropriação da questão social, anteriormente rejeitada como símbolo de um mundo que nascia liberto e independente da religião.

Muito curiosamente, e com implicações importantes para o argumento que estou desenvolvendo, o catolicismo social, a fim de reafirmar o caráter fundante do religioso para a sociedade, contra a ruptura decorrente do processo de secularização, recorre a um problema cujo aparecimento vincula-se, em parte, ao próprio processo que ele quer combater 
(Steil, 1994). ${ }^{17}$ A Rerum Novarum é bastante explícita a esse respeito, chamando a atenção para o fato de que a primeira condição a ser satisfeita para a resolução da questão social é a restauração dos costumes cristãos:

[...] não é duvidoso que a sociedade civil foi essencialmente renovada pelas instituiçōes cristãs, que esta renovação teve por efeito elevar o nível do gênero humano $[. .$.$] como não se viu semelhante nem antes nem depois, e não se$ verá jamais em todo decurso dos séculos [...] É por isso que, se a sociedade humana deve ser curada, não o será senão pelo regresso à vida e às instituições do cristianismo. A quem quer regen erar uma sociedade qualquer em decadência, se prescreve com razão que a reconduza às suas origens. (Leão XIII, 1891).

A Ação Católica, já em nosso século, retoma o mesmo sentido informado por esse uso do conceito de renovação. ${ }^{18}$ Assumindo como seu objetivo explícito a recristianização do mundo moderno, ela associa o conceito de renovação ao retorno a uma sociedade cristã, onde a religião (católica) apareceria como indissociável de sua organização manifesta:

Algo de novo começou e ao nosso ver algo de muito importante, pois abrange o campo imenso da vida da Igreja. Parece que tudo vai receber uma influência

\footnotetext{
17 "O Catolicismo Social pode ser compreendido como um momento de ruptura e continuidade com uma tradição que precisa ser reinventada. A impossibilidade de manter a vigência da religiáo como estruturante do social exige que a Igreja Católica invente outras formas de coesão social, capazes de organizar os elementos da tradição em novas sínteses, onde a ruptura possa se manter referida à tradição. Nesse sentido, a criação de sindicatos, partidos, empresas, congressos católicos ou mesmo de uma doutrina social, revela a capacidade de invenção da instituição. Sem romper radicalmente com a tradição, assume as mesmas formas institucionais e de atuação dos seus adversários." (Steil, 1994, p. 64).

${ }^{18}$ Sobre a trajetória histórica da Ação Católica, a obra do brasilianista Scott Mainwaring (1989) é, certamente, uma das mais completas, particularmente no campo das relações entre a Igreja Católica e a política no Brasil contemporâneo.
} 
renovadora [...] Haverá uma espécie de adaptação à nova mentalidade que por sua vez há de impregnar e renovar tudo, a não ser que o movimento seja embargado no seu começo pela má vontade, a incompreensão, ou a indolência [...] Deus nos livre desta responsabilidade que seria a de impedir, retardar, ou diminuir a recristianização do mundo, fim único da Ação Católica. (Boaventura, 1944, p. 116).

Esse uso do conceito de renovação está informado pela crença na reversibilidade da ruptura. A adaptação de que fala o texto acima é orientada pela vontade de tornar a modernidade uma sociedade cristã, cuja referência é buscada no passado, seja ele próximo, como o do ancien régime, seja distante, quase esquecido, situado nas origens do cristianismo. Ambos constituem um modelo mítico, exemplar, que deve ser atualizado na história, espaço presente onde grassam as agruras decorrentes da ruptura: falta que, ao instituir-se, instituiu o desejo sempre reiterado de sua superação.

Se há um uso do conceito de renovação que o toma como semanticamente equivalente à idéia de inovação, conforme demonstrei no início deste artigo, há uma outra utilização que o define como sinônimo de retorno e continuidade. No primeiro caso, o problema é o cristianismo (catolicismo) separado do mundo, onde a adaptação à sociedade deve obedecer à vontade de tornar o catolicismo impregnado de tudo aquilo que ela, a sociedade, traz de novo e, é claro, de melhor. Seu patrimônio ético e político é um ótimo exemplo. Os direitos humanos, tão veementemente rejeitados pela Igreja quando de seu aparecimento histórico no final do século XVIII, tornam-se não apenas uma de suas grandes bandeiras políticas, como também passam a ser incorporados à sua tradição, chegando-se, inclusive, a falar da Bíblia como a sua carta magna. ${ }^{19}$ Já no segundo caso, o problema é o mundo separado do catolicismo, onde, portanto, a adaptação à sociedade obedece a critério bem distinto, que é o de torná-la novamente cristã. O que se vê nos dois casos é uma relação de tipo circular: onde no primeiro tem-se

${ }^{19}$ Ver Soares-Prabhu (1995). Sobre a atuação da Igreja Católica, ver o trabalho de Pierucci (1996). Sobre a "eticização" das "religiôes universais", consultar Pace (1997). 
uma "socialização do catolicismo", no segundo há uma "catolicização da sociedade". De qualquer maneira, para ambos o problema que parece estar colocado é bastante parecido, talvez por assemelhar-se com aquele, já mencionado, da adaptação (accommodatio).

Há entre estas duas utilizações uma distinção que passa, é certo, pelo crivo político que de longa data opõe "integristas" e "modernistas" ${ }^{20} \mathrm{~A}$ política, no entanto, não esgota a explicação, já que o conceito de renovação demonstra, justamente, a existência de um duplo movimento que, mesmo consideradas as importantes diferenças entre aqueles dois grupos, irá caracterizar a ambos. Assim, do mesmo modo que se pode e deve perguntar quanto de referência ao passado e à continuidade resta no conceito de renovação enquanto equivalente à emergência do novo, o contrário, certamente, também é possível, e talvez mais ainda, necessário: quanto de referência ao novo permanece no conceito de renovação como sinônimo de um retorno ao passado. É preciso deixar claro, portanto, que não se trata aqui de sugerir, como se tornou hoje comum nas palavras do Cardeal Ratzinger, ${ }^{21}$ um "continuísmo", mas sim de argumentar que, no campo católico e cristão, a mudança somente pode ser pensada e realizada na sua relação com aquilo que permanece, e também o inverso: a permanência é o modo assumido pela transformação.

\footnotetext{
${ }^{20}$ Sobre esse conflito, além do já citado Mainwaring (1989), há também o importante trabalho de J. B. Libânio (1983) e o excelente artigo de Antônio Flávio Pierucci (1999), onde se pode ler, por exemplo, o seguinte: "[...] o integrismo formou-se enquanto tal como fruto da crise interior que, no enfrentamento com a sociedade urbano-industrial, o regime democrático e a ciência moderna, fez embarcar em duas direçóes divergentes o catolicismo romano. Uma a favor e querendo avançar ainda mais (os católicos sociais e modernistas) e a outra contra: contra a vontade de modernização que com o pontificado de Leão XIII tomou conta do movimento católico e da própria igreja, sobretudo contra a suposta insanidade de acomodar-se a Igreja à definição republicana e secular do espaço público [...]." (Pierucci, 1999, p. 190-191).

${ }^{21}$ Ver Beozzo (1994, p. 86). O cardeal Ratzinger fala de um Konzils-Ungeist, isto é, um contra-espírito do Concílio Vaticano II; ver Manigne (1984). Sobre a leitura continuísta do Concílio, ver Ladrière (1986).
} 
É interessante observar que a semântica do verbo renovar confirma o duplo processo afirmado anteriormente, onde ao "novo" da palavra renovação vem somar-se uma alusão ao passado: semanticamente a palavra renovação quer significar, a um só tem po, "tornar novo" e "restaurar", "substituir por coisa nova" e "restabelecer". Assim, o sentido desse vocábulo revela a co-presença dessas duas dimensões, a partir das quais ir adiante e retornar a um tempo ido aparecem como coexistentes. Renovar e conservar, sendo que este último pode ser traduzido por restaurar, não são, se observados desse ponto de vista, antônimos. ${ }^{22}$

Trata-se, portanto, de dois sentidos unidos numa única palavra. Neologismo? Talvez. Porém o que decididamente importa é guardar essa ambivalência semântica, pois é ela que vai possibilitar a compreensão da dupla tarefa para a qual o conceito foi fabricado: conservar inovando, ou, nos termos de Marshall Sahlins (1981, 1990), reproduzir transformando. Sempre na tentativa de construir uma síntese entre estabilidade e mudança, passado e presente, tradição e modernidade(s). ${ }^{23}$ Será melhor, a partir de agora, referir-me a ele como "re-novaçáo".

A obra do teólogo Francisco Catão, mencionada no início deste artigo, é uma ótima maneira de verificar a ambivalência que circunscreve o domínio de aplicação desse conceito. A re-novação é entendida como uma palavra que possui a idade do cristianis mo (catolicismo). Ela representa a necessidade de continuamente inseri-lo em todas as contemporaneidades

\footnotetext{
${ }^{22}$ Mircea Eliade, por exemplo, utiliza os termos "renovação" e "resta uração" de modo intercambiável. Ambos designam, segundo o que ele nos diz, a repetição de um mito de origem. "Só se pode renovar o Mundo repetindo o que os imortais fizeram in illo tempore, reiterando a criação." (Eliade, 1991, p. 155).

23 "Somos siempre Heráclito viéndose reflejado en el río, y pensando que el río no es el río porque ha cambiado las aguas, y pensando que él no es Heráclito porque él ha sido otras personas entre la última vez que vio el río y ésta. Es decir, somos algo cambiante y algo permanente. Somos algo esencialmente misterioso [...] Ése es el problema que nunca podremos resolver: el problema de la identidad cambiante [...] Es decir, la idea de la permanencia en lo fugaz." (Borges, 1989, p. 128).
} 
históricas, demonstrando, dessa maneira, que o cristianismo não é uma religião dada, mas um ininterrupto fazer-se, sempre atual às expectativas e à realidade de seu tempo. A "novidade" do Evangelho é novidade em todos os tempos e culturas.

O motivo que explica essa sua permanente novidade é, justamente, a universalidade que lhe é fundante: Pentecostes, o seu mito de origem, é uma narrativa sobre a língua universal, que, ao não vinculá-lo a qualquer sociedade particular, seja no tempo, seja no espaço, o torna inteligível em todos os momentos singulares. As formas históricas que ele assume são incondicionalmente relativas, ao passo que sua comunhão com Deus é sempre trans-histórica. Deve ser vivido na história, mas deve, também, transcendê-la. Há, portanto, uma antitemporalidade que acompanha a sua encarnação no tempo. Desse princípio, colocado pelo Concílio Vaticano II, deriva uma conseqüência sobre a qual, segundo o autor, não se tem chamado bastante atenção: a autenticidade da instituição cristã reside na percepção de uma continuidade de ordem espiritual, que se vai realizando no tempo através de formas em constante evolução, mas que exprimem, sempre de maneira nova, a mesma fé que inspirou os apóstolos (Catão, 1995, p. 10-12).

O permanente reencontro com o mesmo na constante emergência do outro, o eterno retorno do mito no tempo irreversível da história, é isso o que diz o texto acima. ${ }^{24}$ É, também, o que diz a expressão antes mencionada: ascese da ambivalência. Ela, como se pode ver, condição e sentido do conceito de re-novação. Condição, porque é do distanciamento destas duas alteridades (o visível e o invisível, o mito e a história) que pode emergir o

\footnotetext{
24 "A tarefa que a teologia do Vaticano II assumiu de fazer a passagem desse universo absoluto (tridentino), sagrado para o relativo, para as realidades terrestres, sem perder a dimensão transcendental e eterna, é por demais difícil e requer nível elaborado de reflexão. Relacionar a simbólica profunda calcada na força sustentadora do absoluto, do universal, com o diário transitório desafia a Igreja depois do Concílio." (Libânio, 1983, p. 123, grifo meu).
} 
trabalho da re-novação. E sentido, porque representa a tentativa de relacionar os dois, sem comprometer a especificidade de cada um. Tornada, assim, impossível a identidade entre religião e sociedade, e recusada, ao mesmo tempo, a sua irredutível alteridade, o conceito de re-novação aparece com o objetivo de re-encontrar, naquilo que permanece, a mudança.

$\mathrm{Na}$ ruptura entre a sociedade e a religião, tem-se uma condição necessária para a gênese do conceito de re-novação. Mas não é uma condição suficiente. Sua aceitação é, nesse caso, fundamental. Posto que aceitá-la significa não somente reconhecer como legítima a autonomia da sociedade, como também, e mais ainda, implica interiorizar a alteridade social no próprio modo de produção da crença religiosa. "Legítima autonomia das realidades terrestres", como afirmou o Concílio Vaticano II, significa não apenas acatar a fratura entre a "Palavra do crente" e a "linguagem do homem", 25 mas, sobretudo, colocar a incontornável necessidade de encontrar os meios mediante os quais a primeira possa ser eficazmente comunicada na segunda. Não se trata mais de reduzir a "linguagem do homem" à "Palavra do crente", conforme colocada na vontade de recristianização, negação da alteridade através do signo do mesmo, e também não se trata de diluir a segunda na primeira, negação da identidade através do signo do outro, mas de, permanentemente, encontrar o modo mais apropriado de relacionar a identidade e a alteridade, o mesmo e o outro. ${ }^{26} \mathrm{O}$ problema, portanto, não é muito diferente daquele com o qual se defronta, periodicamente, tanto o historiadorquanto o antropólogo: "comocompreender o outro sem sacrificálo à nossa lógica e sem sacrificar a nossa à dele?” (Merleau-Ponty, 1980, p.

${ }^{25}$ Esses termos são de Michel de Certeau; ver Lima Vaz (1968).

${ }^{26} \mathrm{Em}$ um texto publicado três anos após o término do Concílio, Kloppenburg já demonstrava, de certa forma, ter percebido esse horizonte: "A Igreja deve inserir-se no Mundo, in terpenetrar-se com ele, sem com ele identificar-se [...] A cidade terrestre e a cidade celeste são sempre dois pólos que se interpenetram, sem confusão, identificação ou mistura, mas também sem separação ou oposição [...]." (Kloppenburg, 1968, p. 35). 
147). ${ }^{27}$ É esta dramática da conciliação que está colocada nos movimentos de re-novação - aqui novamen te estou pensando no catolicismo carismático e no catolicismo da libertação - que surgiram na Igreja no contexto PósConcílio Vaticano II.

Sabemos que traduzir é o caminho, já comum, através do qual o antropólogo e o historiador buscam resolver aquele problema. Atividade que não é muito diferente daquela que exerce o tradutor de um poema ou de uma obra literária. Também ele deve levar adiante o sentido, vendo-se obrigado a ser fiel, no mesmo movimento, ao poema original, sempre, é claro, através da sua recriação na outra língua (Barbosa, 1986).

Traduzir, escrevia Franz Rosenweig, é servir a dois senhores. Tal é a metáfora ancilar. Trata-se de servir à obra, ao autor, à língua estrangeira (primeiro senhor) e de servir ao público e à língua própria (segundo senhor). Aqui surge o que se pode chamar de drama do tradutor. (Berman, 2002, p. 15).

A tradução, como se sabe, trabalha na comensurabilidade dos sistemas lingüísticos, na possibilidade de comunicação entre um mesmo que nunca é assim tão mesmo, como já demonstrou Jacques Derrida (2002), e um outro que se mostra, da mesma forma, menos outro do que muitas vezes se é capaz de supor. "Tradução não é pura identidade, mas diálogo em busca de identificação, encontro de diferenças” (Kothe, 1983, p. 293). Tradução,

\footnotetext{
27 "La crisis del cristianismo moderno puede resumirse, pues, en los siguientes términos: si defiende su vieja idea de lo sacro como una esfera radicalmente distinta de lo profano, en la pujante civilización moderna corre el riesgo de convertirse en una secta apergaminada que, para conservar su posición, debería luchar en un mundo que cada día que pase entenderá menos semejante cristianismo; si acepta las tesis de Teillhard y los teólogos que llevan hasta sus últimas consecuencias la idea del mundo empírico como manifestación de Dios, podrá retener muchos de sus con tenidos, pero lo específicamente cristiano - sus dogmas, iglesias y ceremonias - se extinguirá.” (Kolakowski, 1971, p. 88). Essa ambivalência entre lugar e não-lugar, que Kolakowski chama de crise, é, propriamente, o espaço onde o catolicismo deve negociar a sua visibilidade e influência públicas: espaço ocupado pelo conceito de re-novação.
} 
desse modo, quer dizer, ao mesmo tempo, busca pelo sentido e produção do sentido no ato de buscá-lo. De outro modo, significa, apenas e tãosomente, interpretação.

O conceito de re-novação, assim como o seu homólogo adequação, também recobre, nesses moldes, uma experiência de tradução, trazendo, em si mesmo, a possibilidade de um procedimento hermenêutico. Nesse sentido, re-novar significa, igualmente, traduzir. O problema aqui é o da passagem entre o crer e o dizer no contexto da comunicação entre a sociedade moderna e a Igreja Católica. O filósofo e teólogo Henrique de Lima Vaz, citando Michel de Certeau, o formulou da seguinte maneira:

Como o cristão (católico) falará a sua Fé? E se esse falar é essencial à dimensão sócio-institucional dessa mesma Fé, à sua dimensão eclesial, a questão se amplia e se impõe como questão radical: como a Igreja falará a Fé ao mundo de hoje? Qual será a sua linguagem? [...] Como poderão os cristãos - a Igreja - anunciar a Mensagem nessas novas linguagens que traduzem uma dominadora presença do homem na Naturezae nas articulaçóes fundamentais da sua própria história? (Lima Vaz, 1968, p. 16,18).28

Em outras palavras, como falar a um mundo cuja disposição para ouvir deixou de ser um dado a priori da crença de quem fala? A re-novação atua, justamente, neste espaço de comunicação que deve ser continuamente fabricado. ${ }^{29}$ Re-novar aparece, então, como tradução que busca, na tradi-

${ }^{28}$ Estas mesmas indagações poderiam ser formuladas de dois outros modos. Na pergunta de Mich el de Certeau (1987, p. 269), "como produzir uma linguagem cren te?", presente em sua obra póstuma, ou adotando os termos de Peter Berger (1985): como produzir uma estrutura de plausibilidade?

${ }^{29} \mathrm{O}$ papa João XXIII percebeu um lado dessa questão quando afirmou que "a grande preocupação, hoje, é e deve ser: como tornar-nos inteligíveis aqui e agora”; e quando admoestou aos teólogos: "procurem incessantemente maneiras mais adaptadas de comunicar a doutrina cristã aos homens de seu tempo" (apud Kloppenburg, 1968, p. 34). O outro lado consistiria em reconhecer que a expressão encontra-se indissociavelmente vinculada ao conteúdo. 
ção, o melhor modo de expressar-se modernamente. ${ }^{30}$ É por ser uma tradução que o conceito de re-novação não é nem igual à inovação, nem à restauração. É, isso sim, re-encon tro $\mathrm{da}(\mathrm{s})$ modernidade(s) naquilo que ela representa (re-apresenta) de emergência do novo na tradição e no passado.

Todas essas questóes aparecem muito claramente no catolicismo da libertaçáo. A "nova Igrej a" que dele resulta, Igreja Popular, propóe recuperar uma dimensão que é, no seu entendimento, a verdadeira e original da Igreja: a sua dimensão preferencial pelo oprimido. Deus revela-se no rosto do fraco. Esse aspecto ético e político da revelação teria sido esquecido, no transcurso do processo histórico, em decorrência da aliança que a Igreja fez com os poderosos. Desse modo, a nova teologia e a nova hermenêutica, que propõem realizar a "nova Igreja", percebem a si mesmas como uma tentativa de retomar o passado e nele reencontrar o sentido original de um cristianismo que se perdeu. É pela fidelidade à tradição que elas reivindicam o ser outro.

De fato, a nova Igreja é a recuperação da verdadeira Igreja, cuja essência, apesar de se estar assumindo a historicidade da prática humana continua a pairar acima desta historicidade. Se o Verbo se encarna na história, continua supra-histórico e um a priori da história. Assim, recuperando-se o pobre recupera-se o verdadeiro e original sentido da Igreja. Recupera-se, também, a possibilidade objetiva de reencontrar um lugar de autoridade para a fala da Igreja como o lugar da verdade revelada por Deus. (Macedo, 1986, p. 72, grifo da autora).

Pouco mais precisaria ser dito. Há um silêncio sobre o qual o conceito de re-novação se apóia: é o esquecimento de outra voz que também estava

\footnotetext{
${ }^{30}$ Somente o sentido mais radical da tradução, afirmou o crítico literário João Alexandre Barbosa, permite a crença de que é possível ser de todas as épocas e de todos os lugares. Deste modo é que se pode entender que os conceitos, aparentemente contraditórios, de tradução e tradição podem funcionar, pelo menos circunstancialmente, para designar um problema muito parecido: aquele referente à transferência, ou seja, o ato de transportar entre fronteiras; ver Barbosa (1986, p. 155) e Hall (1997, p. 96).
} 
presente na tradição. ${ }^{31}$ Re-novar é, igualmente, um artifício de recriação da memória católica, logo, de recriação de sua tradição. É, como a profecia, memória do futuro. Pois é como se todos os futuros possíveis e imprevisíveis estivessem desde já encravados num passado silencioso, onde o trabalho de re-novar consistiria em fazê-los emergir pela memória que cria, ao imaginar que reitera. Melhor: pela memória que cria, reiterando. As novidades históricas, como os direitos humanos, a política, os carismas, seriam atualizações dessa realidade desde sempre presente. Mítica, portanto.

O conceito de re-novação demonstra que as inovações são tradicionais. Numa primeira etapa, a novidade é captada pela tradição, para ser, em seguida, a força de sua transformação. Nesse sentido, a re-novação revela uma forma destradicional de relacionamento com a tradição, cujo sentido de autoridade torna-se, a cada retorno, parte do que está antes apenas na alteridade daquilo que, proveniente do que veio depois, é agora presente. Estabelecendo, dessa forma, uma relação indissociável entre passado e atualidade, a tradição aparece, simultaneamente, como tradicional e moderna. ${ }^{32}$ Portanto, a "nostalgia da origem" que acompanha os catolicismos re-novadores é, ao mesmo tempo, "nostalgia do presente". De modo que o conceito de re-novação também revela que a tradição é inovadora.

Últimas aproximações. Re-novação: conceito que traduz, na sua necessidade de tradução, a ruptura que o torna possível e o trabalho que visa a estabelecer uma semelhança na própria alteridade. Re-novação: tradução. Traduzir: encontrar na tradição a modernidade e, nesse processo, recriar

\footnotetext{
31 "Mallarmé sabia: existem poemas porque não existe o poema. Fragmentos de um texto que a tradição esqueceu e que a tradução procura recuperar." (Barbosa, 1986, p. 31). O mesmo talvez se possa dizer sobre a re-novação: a vida da tradição é o(s) silêncio(s) sobre o(s) qual(is) emerge o trabalho da interpretação, e, portanto, da tradução.

32 "A Escritu ra e a tradição", afirma Peter Schineller, "são um grand e e diversificado baú, e não ta nto um sólido bloco de ouro” (Schin eller, 1989, p. 94).
} 
modernamente a própria tradição. ${ }^{33}$ Fazendo assim o jogo desse conceito, inscrito no paradoxo do retorno, signo de uma repetição instauradora da diferença, o "catolicismo" - no modo, é claro, como é produzido e reproduzido pelos "catolicismos re-novadores" - pode então se encon trar on de não estava, experimentando-o, no entanto, como se sempre tivesse estado ali, isto é, experimentando-o como o seu duplo, que, se por um lado, não cessa de fazê-lo parecer-se com a imagem sempre deslocada de si mesmo, por outro, torna-se a condição do seu reencontro possível, da relação que o leva, a cada vez, de si para si.

\section{REFERÊNCIAS}

ANTONIAZZI, Alberto. O catolicismo no Brasil. In: SINAIS dos tempos: diversidade religiosa no Brasil. Rio de Janeiro: ISER, 1993. p. 13-35.

AUBERT, R.; HAJJAR, J. (Org.). Nova história da Igreja: a Igreja na sociedade liberal e no mundo moderno III. Petrópolis: Vozes, 1976.

BARB OSA, João Alexandre. As ilusões da modernidade. São Paulo: Perspectiva, 1986.

BARBOSA NETO, Edgar Rodrigues. O conceito de renovação no catolicismo carismático. Dissertação (Mestrado em Antropologia Social)-PPGAS, Universidade Federal do Rio Grande do Sul, Porto Alegre, 2000.

\footnotetext{
${ }^{33} \mathrm{O}$ poeta Haroldo de Campos defende, em sua proposta de uma "poética sincrônica", a idéia, que ele encontra em Pound, da tradução como uma forma crítico-criativa de reinventar a tradição. Para ele, a permanênciaé, no fundo, feita pela entrosagem diacrônica de leituras sincrônicas do passado (Campos, 1969). Suponho, como uma hipótese mais geral que apenas posso, nesse momento, sugerir, que haja um conjunto significativo de semelhanças a serem exploradas entre a experiência do tempo e da linguagem tal como o conceito de re-novação nos permite observar e outras formas dessas duas experiências que parecem emergir em algumas manifestações da arte contemporânea e mesmo de algumas reflexôes feitas a seu respeito.
} 
BEOZZO, José Oscar. A Igreja do Brasil: de João XXIII a João Paulo II: de Medellin a Santo Domingo. Petrópolis: Vozes, 1994.

BERGER, Peter. $O$ dossel sagrado: elementos para uma teoria sociológica da religião. São Paulo: Paulus, 1985.

BEYER, PeterF. A privatizaçãoe a influênciapública da religiāo na sociedade global. In: FEATHERSTONE, Mike (Org.). Cultura global: nacionalismo, globalização e modernidade. Petrópolis: Vozes, 1994.

BERMAN, Antoine. A prova do estrangeiro. cultura e tradução na Alemanha romântica. Bauru: EDUSC, 2002.

BOAVENTURA, Frei (O.P.). Ação Católica: novidade na Igreja. Revista Eclesiática Brasileira, 1944.

BOFF, Clodovis. O que mudou na teoria do cristianismo de 20 anos para cá. Revista de CulturaVozes, Petrópolis, ano 76, n. 1, p. 5-14, jan./fev. 1982.

BOLTON, Brenda. A Reforma na Idade Média. Lisboa: Edições 70, 1983.

BORGES, Jorge Luis. El tiempo. In: BORGES Oral: conferencias. Buenos Aires: EMECÉ/Editorial de Belgrano, 1989. p. 107-129.

BORNHEIM, Gerd. Observações sobre a presença da metafísica platônica no pensamento de Santo Agostinho. In: . Metafisica e finitude. Porto Alegre: Editora Movimento/IPV, 1972. p. 14-34.

CAMPOS, Haroldo de. A arte no horizonte do provável. São Paulo: Perspectiva, 1969.

CATÃO, Francisco. Carismáticos, um sopro de renovação. São Paulo: Ed. Salesiana Dom Bosco, 1995.

CERTEAU, Michel de. La faiblesse de croire. Paris: Éditions du Seuil, 1987. . A invenção do cotidiano. Petrópolis: Vozes, 1994.

CONGAR, Yves. La Tradition et les traditions: essai historique. Paris: Gallimard, 1960. 
CROATTO, José Severino. A relevância sócio-histórica e hermenêutica do êxodo. Concilium, Petrópolis, v. 209, n. 1, p. 133-141, 1987.

DEN BORN, A. Van et al. Dicionário enciclopédico da Bíblia. Petrópolis: Vozes, 1985.

DERRIDA, Jacques. Torres de Babel. Belo Horizonte: Ed. UFMG, 2002.

DUPRONT, Alphonse. A religiāo católica: possibilidades e perspectivas. São Paulo: Loyola, 1995.

ELIADE, Mircea. Les naissances mystiques. Paris: Gallimard, 1959.

Mefistófeles e o andrógino. São Paulo: Martins Fontes, 1991.

GANDILLAC, Maurice de. Gêneses da modernidade. Rio de Janeiro: Ed. 34, 1995.

GINZBURG, Carlo. Olhos de madeira: nove reflexôes sobre a distância. São Paulo: Companhia das Letras, 2001.

GREINACHER, Norbert. Identidade católica na terceira era da história da Igreja: o Concílio Vaticano II e suas conseqüências para a teoria e a prática da Igreja Católica. Concilium, Petrópolis, v. 255, n. 5, p. 8-22, 1994.

GUIZZARDI, Gustavo; STELLA, Renato. Teorias da secularização. In: FERRAROTI, F. et al. Sociologia da religião. São Paulo: Paulinas, 1990. p. 203-249.

HALL, Stuart. A identidade cultural na pós-modernidade. Rio de Janeiro: DP\&A, 1997.

KERKHOFS, Jan. A Igreja e seus intelectuais. In: LUNEAU, René; MICHEL, Patrick (Org.). Nem todos os caminhos levam a Roma: as mutaçóes atuais do catolicismo. Petrópolis: Vozes, 1999.

KLOPPENBURG, Boaventura. Por uma Igreja interpen etrada com o mundo. Revista Eclesiástica Brasileira, v. 28, fasc. 1, 1968.

KOLAKOWSKI, Leszek. Vigencia y caducidad de las tradiciones cristianas. Buenos Aires: Amorrotu Editores, 1971. 
KOTHE, Flávio. A questão da tradução. In: MARX, Karl. O capital. São Paulo: Abril Cultural, 1983. v. 1.

LADRIÈRE, Paul. Le catholicisme entre deux interprétations du Concile Vatican II: le Synode Extraordinaire de 1985. Archives de Sciences Sociales des Religions, v. 62, n. 1, p. 9-51, 1986.

LEÃO XIII. Rerum Novarum. Vaticano, 1891. Disponível em: <http:// www.montfort.org.br/documentos/rerumnovarum.html>.

LEÓN-DUFOUR, Xavier et al.. Vocabulário de teologia bíblica. Petrópolis: Vozes, 1984.

LIBÂNIO, J. B. A volta à grande disciplina. São Paulo: Loyola, 1983.

LIMA VAZ, Henrique C. de. Cristianismo e mundo moderno: posição e evolução do problema. Paz e Terra, Rio de Janeiro, ano 2, n. 6, p. 5-20, 1968.

Fé e linguagem. In: - Escritos de filosofia I: problemas de fronteira. São Paulo: Loyola, 1986.

MACEDO, Carmen Cinira de. Tempo de Gênesis. o povo das Comunidades Eclesiais de Base. São Paulo: Brasiliense, 1986.

MACKENZIE, John L. Dicionário bíblico. São Paulo: Paulinas, 1983.

MAINWARING, Scott. Igreja Católica e politica no Brasil (1916-1985). São Paulo: Brasiliense, 1989.

MANIGNE, Jean-Pierre. La "Restauration" selon Mgr Ratzinger. L'Actualité Religeuse dans le Monde, n. 18-15, p. 29-31, déc. 1984.

MERLEAU-PONTY, Maurice. De Mauss a Claude Lévi-Strauss. In: MERLEAU-PONTY. São Paulo: Abril Cultural, 1980. p. 193-206. (Coleção Os Pensadores).

MONTERO, Paula (Coord.). Entre o mito e a história: o v centenário do descobrimento da América. Petrópolis: Vozes, 1996. 
OLIVEIRA,P. R. de. Analise sociológica da Renovaçáo Carismática Católica. In: OLIVEIRA, P. R. de; BOFF, L.; LIBÂNIO, J. B.; BITTENCOURT, E. Renovação Carismática Católica. Petrópolis: Vozes, 1978.

PACE, Enzo. Religião e globalização. In: ORO, Ari Pedro; STEIL, Carlos Alberto (Org.). Globalização e religiāo. Petrópolis: Vozes, 1997.

PIERUCCI, Antônio Flávio. Religião e liberdade, religiōes e liberdades. In: PIERUCCI, Antônio Flávio; PRANDI, Reginaldo. A realidade social das religióes no Brasil. São Paulo: Curso de Pós-Graduação em Sociologia da Universidade de São Paulo: HUCITEC, 1996. p. 241-256.

Fundamentalismo e integrismo: os nomes e a coisa. In:

Ciladas da diferença. São Paulo: Curso de Pós-Graduação em Sociologia da Universidade de São Paulo: Ed. 34, 1999. p. 177-200.

PRANDI, Reginaldo. Um sopro do Espírito Santo. São Paulo: EDUSP/ FAPESP, 1997.

REHFELD, Walter I. Tempo e religião: a experiência do homem bíblico. São Paulo: Perspectiva: EDUSP, 1988.

RICOEUR, Paul; LACOCQUE, André. Pensando biblicamente. Bauru: EDUSC, 2001.

SAHLINS, Marshall. Historical metaphors and mythical realities. structure in the early History of the Sandwich Islands Kingdom. Ann Harbor: University of Michigan Press, 1981.

. Ilhas de história. Rio de Janeiro: Jorge Zahar, 1990.

SANCHIS, Pierre. Uma identidade católica? Comunicações do ISER, Rio de Janeiro, n. 22, p. 5-16, 1986.

Catolicismo,entre tradição e modernidades. Comunicaçôesdo ISER, Rio de Janeiro, n. 44, p. 9-24, 1993.

SCHINELLER,Peter. Inculturação como peregrinaçãorumo à catolicidade. Concilium, Petrópolis, v. 224, n. 4, p. 93-101, 1989. 